\title{
Učitel, nebo chůva? \\ Obsah a učivo jako memento \\ učitelské profese
}

\author{
Jan Slavík, Stanislav Štech, Klára UIičná
}

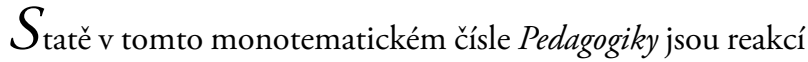
na redakční výzvu autorům ${ }^{1}$ opřenou o dvě klíčová témata: analýza učiva a vyprazdñováni obsahu. Obě témata navzájem úzce souvisejí. Platí-li totiž předpoklad, že ve školní praxi i v pedagogické teorii dochází $\mathrm{k}$,wyprazdňování obsahu“, tj. k oslabování pozornosti $\mathrm{k}$ učivu, pak by to nepochybně mělo postihnout též kvalitu analýzy učiva.

Kvalita analýzy učiva a $s$ ní též vzdělávací obsah a jeho transformace ve výuce jsou tradiční doménou oborových didaktik. Avšak ze širšiho transdisciplinárního hlediska sahá tematika obsahu, učiva a jeho analýz daleko za rámec didaktik jednotlivých vzdělávacích oborů, protože představuje hlavní „legitimizaci“ pedagogického vztahu mezi žáky a učiteli. Úzce se přitom týká součinnosti mezi teorií a praxí ve vzdělávání a spolu s ní i kvality prípravy učitelů. Obsah, resp. učivo, ${ }^{2}$ je totiž tím, co prostřednictvím oborových didaktik spojuje specializovanou tematiku prírodovědných, sociohumanitních nebo technických disciplín (stojících v kulturním zázemí vzdělávacích oborů či oblastí) nejenom s pedagogikou nebo psychologií, ale současně i se vzdělávací praxí, jejímž cílem má být, aby se žáci něčemu - obsahu - naučili.

Nezabývat se obsahem vyučování a učení je tedy v obecném smyslu totéž jako rezignovat nejenom na zvláštní učitelskou

\footnotetext{
${ }^{1}$ Text výzvy je dostupný na <http://pages.pedf.cuni.cz/pedagogika/?p=11485\&lang=cs>.

${ }^{2}$ Pojmy obsah, učivo se zčásti kryjí, ale nelze je zaměňovat. V tradičním didaktickém pojetí se obsahem rozumí vše, co se lze učit a naučit (včetně pohybových a tvůrčích dispozic). Učivo je záměrně vybraný obsah určený $\mathrm{k}$ vyučování a učení a zpravidla kodifikovaný v kurikulárních dokumentech (srov. Janík, 2009, s. 138-139).
} 
problematiku vztahů mezi vyučováním (učitele) a učením (žáků) v učebních úlohách, ale také na tematiku vzdělávacích a výchovných cílů. Jinak řečeno, znamená to ztratit ze zřetele kurikulum, jeho teorii a spolu s ní též obecnou didaktiku, má-li plnit roli zastřešující disciplíny oborových didaktik. $\mathrm{V}$ tom případě ovšem teorie zřetelně ztrácí své klíčové profesní zakotvení ve vzdělávací praxi, protože učitel bez učiva, bez didaktiky jako překladu předávaných poznatků „očima žákü“ a bez kurikula $s$ jeho cíli přestává být učitelem v profesním smyslu toho slova a mění se $\mathrm{v}$ naivní chůvu nebo $\mathrm{v}$ lepším př́padě $\mathrm{v}$ socioterapeuta.

Z toho všeho současně plyne, že negativním důsledkem systémové ztráty zřetele $\mathrm{k} \mathrm{ob-}$ sahu (tj. důsledkem vyprazdňování obsahu) je rozpad účinné a neformální spolupráce mezi vzdělávací teorií a praxí ve vzdělávání. Způsoby či metody vyučování a učení „samy o sobě “ jsou při realizaci prázdné nebo se mění jen ve víceméně nezávaznou sociální hru: bez obsahu ztrácejí vzdělávací hodnotu i kulturní autoritu. Zkrátka a jednoduše, měl by snad sebekrásnější dialog učitele se žáky smysl pro vzdělávání, kdyby byl „o ničem“?

Předcházející odstavce měly naznačit, že tematika vzdělávacího obsahu spolu s analýzou učiva zahrnuje důležité a komplexní problémy spojené $s$ kurikulem, $s$ hodnocením výuky, s proměnami její kvality a s př́pravou učitelů. Celé toto široké a badatelsky náročné pole bylo nabídkou pro autory monotematického čísla. Původním záměrem této nabídky bylo především podpořit epistemologickou analýzu učiva a spolu s ní obecnější didaktickou nebo kurikulární problematiku zkoumání vztahů mezi obsahem, který vstupuje do výuky z kultury, a utvárením významů, které jsou konstituovány žáky v učebním prostředí (relace Inhalt-Gehalt v aktuálním pojetí německé didaktiky; srov. Hopmann, 2007; Janík \& Stuchlíková, 2010, s. 10-11).

Učitel sice obsah vybírá a usiluje o jeho zpřístupnění žákům, avšak těmi, kdo z něj v sociálním prostředí mají autonomně a s porozuměním konstruovat své vlastní významy, jsou žáci sami. Teprve tím se obsah realizuje a stává se plnohodnotným učivem, tj. učivem nejen formálně zachyceným v kurikulárním dokumentu, ale personalizovaným jako součást žákových vlastních mentálních dispozic a tělesných sil. Proto by učitel měl být profesně dobře vybaven kompetencemi pro analýzu učiva na onom klíčovém rozhraní mezi obsahem a jeho zvýznamňováním během výuky. Teoretické nebo výzkumné studie, diskusní příspěvky i recenze v tomto čísle Pedagogiky přistupují k takto nastolenému tématu z rozmanitých hledisek, ale ve zřetelně společném myšlenkovém rámci.

Teoretická studie D. Dvořáka Sociálni realismus: teorie vzdělávacího obsahu a jeho predáváni už svým názvem vymezuje základní opěrné body aktuální renesance zájmu o učivo. „Sociální realismus“ připomíná, že žákovo učení není a ani nemůže být relativní konstrukcí vědomostí podmíněnou hlavně jeho individuální zkušeností, ale že musí především respektovat poznatky existující mimo a před touto zkušeností a musí zvládnout závazné zacházení s nimi. Nejen to, je to činnost sociálně podmíněná. To, co se učíme, je vždycky dílem konkrétních lidí, kteří jsou sami nějak sociálně situováni, mají své - i sku- 
pinové, sociální a v důsledku mocenské - zájmy. Má to však i sociální důsledky. Pojetí učiva (jeho rámování, klasifikace, obecně - způsoby kódování) ovlivňuje školní a následně i sociální úspěšnost různých skupin žáků různě. Akademické znalosti a nároky na jejich závazné osvojení přitom nemohou zůstat jen výsadou těch sociokulturně lépe vybavených dětí. Rehabilitace vzdělávacího obsahu spočívá podle některých realistů v kombinaci respektování závazné pojmové struktury učiva s variabilitou metod nezavrhujících ani dril, procvičování, aplikace a zahrnujících inovativní metody výuky. Je to jediná možná cesta, jak skutečně pomoci k efektivnímu vzdělání dětem ze všech sociálních vrstev.

Petr Najvar ve své teoretické studii nazvané Zkoumáni (kvality) výuky: srovnání dvou prístupio cílí na problematiku validity výzkumů procesu výuky a hodnocení její kvality. Tyto výzkumy jsou podle autora „bytostně didaktické“, nebot se zaměřují na porozumění vztahům mezi kvalitami učebního prostředí a kvalitami žákovského porozumění vzdělávacímu obsahu. Narážejí však na problém „mezery“ mezi popisem pozorovaných vlastností výuky a hodnocením jejich př́nosu pro žáky, protože kauzální vztah mezi reálným stavem výuky a jeho působením na žáka nelze přímo pozorovat. Najvar se zaměruje na osvětlení tohoto problému prostřednictvím srovnání dvou výzkumných strategií s rozdílným designem: kvantitativním a kvalitativním. Opírá se přitom o detailní porovnávání dvou prototypů výzkumu, s nimiž má vlastní dlouhodobě rozvíjenou badatelskou zkušenost. Kvantitativní design (v podobě tzv. předem strukturované reflexe) je reprezentován metodikou videostudií, zatímco kvalitativní př́stup (v podobě reflexe následně strukturované) je zastoupen metodikou $3 \mathrm{~A}$. Ve videostudiích je zmiňovaná „mezera“ překlenuta výkladem korelací mezi změřeným žákovským výkonem (v testu) a kvantifikovanými charakteristikami zkoumané výuky. Na tomto základě lze usuzovat o kvalitě výuky, ale za cenu ztráty zřetele $\mathrm{k}$ transformacím obsahu v učebním prostředí. Oproti tomu v metodice $3 \mathrm{~A}$ je „mezera“ přemostěna interpretováním vztahů mezi analyzovaným stavem učebního prostředí a jeho hodnotovými alternativami (tzv. alteracemi). To umožňuje vysvětlovat „hloubkové“ procesy sémantizace v učebním prostředí, které podmiňují kvalitu výuky, s ohledem na rozvoj instrumentální zkušenosti žáka v př́ślušném oboru. Chybí tu však následná kontrola kvality žákova výkonu. Každý z Najvarem komparovaných přístupů tedy přináší o učebním prostředí poznatky, které jiným způsobem nelze získat.

Výzkumná studie Z. Šalamounové, K. Šed’ové, M. Sedláčka a R. Švaříčka se pod hlavičkou Problém účelnosti v dialogickém vyučováni věnuje problematice „bezúčelných“ pasáží výuky, které neuspokojivě podporují žákovskou poznávací práci s obsahem. Výklad se opírá o zjištění získaná v rámci intervenčního výzkumného projektu, v němž skupina učitelů prošla programem profesního rozvoje, který vedl učitele $\mathrm{k}$ implementaci postupů tzv. dialogického vyučování do jejich výuky. Autoři ve své studii nejprve objasňují hlavní charakteristiky, indikátory a principy dialogického vyučování a poté se zaměřují na princip účelnosti, jehož splnění ve výuce je indikováno tím, že komunikace a interakce jsou podřizeny stanoveným vzdělávacím cílům. Odchylky od principu účelnosti ozna- 
čují autoři za projevy didaktického formalismu specifikované (v souladu s terminologií metodiky 3A) jako tzv. utajené poznávání nebo odcizené poznávání obsahu. Výzkum provedený $\mathrm{v}$ kvalitativním designu se soustředil na studium konkrétní podoby narušování principu účelnosti, resp. oněch zmíněných didaktických formalismů, ve vyučovacích hodinách. Vedl k vytvoření typologie situací, v nichž dochází k porušení účelnosti. Typologie je doplněna vysvětlením důvodů tohoto porušení. Autoři dospěli k charakteristice typových kategorií, které reprezentují různé způsoby „bezúčelnosti“, resp. didaktického formalismu. Podle výzkumných zjištění vznikají bezúčelné pasáže dvojím způsobem: jednak v důsledku nečekaného vývoje oproti plánu, který měl učitel pro výuku připravený, jednak v důsledku nezacíleného, nedostatečně promyšleného převzetí výukové metody. Odbočení od plánu hodiny je př́íznačným rizikem dialogického vyučování spojeným se zvýšenou kognitivní aktivitou žáků, avšak pro učitele nebývá snadné na ni účelně reagovat tak, aby udržel původní zacílení výuky. Nezacílené převzetí výukové metody, tzn. převzetí metody bez promyšlení jejího smyslu a cíle, si podle autorů zasluhuje zvlášt soustředěnou pozornost, protože patrně má obecnější platnost, která přesahuje rámec dialogického vyučování. Jedná se o „mechanické“ přebírání líbivých metod bez ohledu na hlubší analýzu jejich funkčnosti ve vztahu k obsahu, který má metoda žákům zprostředkovat.

Jaroslav Vala se ve své výzkumné studii Komenského spisy jako četba žákiu základni školy? věnuje problematice pojetí obsahu ve spojení s metodami literární výchovy na základních školách. Zaměřil se na rozporný vztah mezi dvěma víceméně antagonistickými př́stupy: př́stupem zacíleným na rozvoj čtenářských návyků, schopnosti tvořivé recepce, interpretace i produkce literárního textu na straně jedné oproti tzv. faktografickému pojetí na straně druhé. Zatímco první z uvedených př́stupů je požadován současnými kurikulárními dokumenty, v reálné vzdělávací praxi podle autora panuje spíše druhý, faktografický přístup. Východiskem pro Valův výzkum je otázka, v čem a do jaké míry se texty, s nimiž se žáci setkávají v literární výchově, podílejí na rozvoji jejich čtenářství. Autor ve výzkumu analyzoval čtenářskou recepci osmi odlišných literárních ukázek žáky devátého ročníku základní školy. Vybral pro něj dvě odlišné skupiny literárních děl: jednak texty z čítanek, které chápe jako „čítankový kánon“, jednak texty ze současné literatury pro mládež. Výzkumem byly vyhodnoceny rozdíly v jejich čtenářském přijetí. Výzkum měl smíšený design: v kvantitativní části výzkumu využil autor metodu sémantického diferenciálu, kvalitativní část šetření byla uskutečněna metodou ohniskových skupin. Ukázalo se, že překážkou sémantizace textu je pro žáky zejména málo srozumitelný jazyk, který znemožňuje sémantické vyznění některých literárních děl objevujících se v čítankách. Autor v závěru konstatuje, že je žádoucí ovlivňovat čtenářství žáků směrem $\mathrm{k}$ vy̌šsí kvalitě, ale současně nesmí být opomíjeny nároky na nezbytnou výchozí prístupnost textu pro žákovskou interpretaci, protože jinak hrozí, že výuka ztratí kvalitu vinou didaktických formalismů.

Rubrika Diskuse je v tomto čísle Pedagogiky tvořena dvěma př́spěvky, které spolu nevedou polemiku, ale vzájemně se podporují. Zuzana Danišková (Má význam bránit' 
"neproduktivne“ vzdelávacie obsahy $v$ dnešných časoch?) se zamýšlí nad konfliktem mezi neoliberálními nároky na účelově chápanou „produktivnost“ vzdělávání a výše zde již zmiňovanou obranou obsahu. Danišková vysvětluje, že tato obrana má smysl tehdy, pokud obsah vzdělávání nezůstane, Bergsonovými slovy, „mrtvými listy na hladině rybníka“, ale bude pro žáky pozvánkou a vstupní branou pro otevření světa oborů, protože „vzdělání je schopností rozumět“ (Rosenzweig). Současně s požadavkem na hloubku a smysluplnost poznání se tu klade nárok na proměnu člověka. Vztah člověka k poznání přece určuje jeho život, jeho činnosti v soukromí, jeho vztahy k ostatním, k obci, jak vysvětluje Patočka. Proto by škola neměla žákům poskytovat jen bezprostředně prakticky využitelné instrukce, ale měla by je naučit „chtít něco vyššího“ a v tomto smyslu se měnit. S tím souvisí potřeba nepodbízet se vžitým hodnotám a navyklému vkusu žáků, ale naopak pomoci jim překonávat omezené perspektivy a dát jim možnost emancipovat se od komunity, na níž jsou přirozeně závislí. To se neobejde bez „přítomnosti vysoké kultury v obsahu školy“, zdůrazňuje Danišková, a připomíná, že tento požadavek spojený se vzdělávacím hlediskem a nárokem na hloubku porozumění zahrnuje i apel na mravnost.

Petr Urbánek ve své odezvě (Smysl má bránit jakékoli vzdélávaci obsahy) příspěvku Z. Daniškové přitakává. Obsah ve výchově je podle jeho mínění určován jejími cíli, nikoli ekonomizovanou "produktivitou“ nebo „(ne)potřebnosti“, přičemž problém současné postmoderní společnosti „tkví právě v neurčitosti a nejasnosti cílü“. Urbánek spojuje tlak na vyprazdňování obsahu ze školy se širším společenským tématem: $s$ destrukcí školy jako instituce. V této souvislosti poukazuje na negaci závažných kulturních hodnot „ideologií účelnosti“, která vede k vykořenění tradice, kontinuity, historické paměti. Proto obsah vzdělávání nemůže být omezen na pouhý výčet právě potřebných znalostí či dovedností, které společnost aktuálně vyžaduje. Týká se to i vzdělávání učitelů. Také v něm je podle Urbánka nedostatečné redukovat vzdělávací obsah jen na účelově pojaté „tréninky“ dovedností pro praxi, jestliže není „akcentována znalost obsahu nebo didaktická práce s učivem jako zcela klíčová učitelská aktivita“. Jednostranný tlak ve prospěch prakticismu má nadto i podstatný koncepční důsledek: zpochybňuje a přehližži „dlouholeté úsilí a ideový zápas za vysokoškolskou př́pravu učitelü“ a nezbytnost „kultivovat studenty a budoucí učitele akademickými obsahy“, zdůrazňuje P. Urbánek v závěru svého př́spěvku.

Recenze Kvaszovy knihy Inštrumentálny realizmus svým pojetím souzní s diskusními př́spěvky, protože poukazuje na jeden jejich důležitý argument pro zachování zřetele k obsahu: nárok na hloubku porozumění. Kvaszova kniha je z tohoto hlediska ilustrativní hlavně proto, že se zabývá matematikou, a to nikoli jen matematikou samotnou, ale především jejím vztahem ke třem sférám, které by měly zvlášt zajímat didaktiku: nejprve se jedná o lidskou zkušenost, následně o to, čemu říkáme „skutečnost“, a nakonec jde o způsob, jak se prostřednictvím zkušenosti propracovat jednak k oboru, jednak ke skutečnosti. Tím se otevírá cesta $\mathrm{k}$ porozumění způsobům, jak vysoce abstraktní obsah matematiky vstupuje do konkrétní historie lidského poznávání světa. Autor recenze připomíná, že 
s ohledem na epistemologicky i ontologicky výjimečnou povahu matematiky se tu nabízí přemýšlení $v$ nejširších souvislostech, napříc rozmanitými obory. Již to by měl být počáteční dost působivý podnět, aby si čtenár recenze povšiml a pustil se do pozorného studia Kvaszovy publikace.

Tolik stručné seznámení s náplní monotematického čísla. Jeho garanti jsou přesvědčeni, že tematika obsahu a učiva $\mathrm{v}$ lecčems přesahuje výlučně akademický rámec a má v mnoha ohledech charakter diskurzu ve Foucaultově smyslu. Je tím míněn diskurz jako historicky proměnlivé pole výpovědí zrozených určitým způsobem myšlení a provázených působením sociokulturních sil, které více či méně skrytě podmiňují utváření, vývoj, příjímání nebo vylučování určitých názorů či přesvědčení. Není zřejmě náhodou, že právě diskurz spojený s obsahem či učivem a způsobem jeho zprostředkování ve škole je již dlouhá léta ve veřejném prostoru relativně nejvíce nasycen diskusemi a polemikami: je žhavou půdou pro mediální debaty o tom, co a jak by se mělo ve školách učit, ale je též diskusním polem, v němž se tematizuje specifické konkurenční napětí mezi „učitelským“ a „ne-učitelským“ vzděláváním (srov. Štech, 2001).

$\mathrm{Z}$ toho důvodu po konzultacích s redakční radou našeho časopisu doplňujeme tento úvodník ještě zvláštní statí: výběrovým ohlédnutím za vývojem přístupů k obsahu vzdělávání, učivu a kurikulu po roce 1989 (v něm je též uvedena bibliografie k této úvodní části). Máme za to, že oněch 28 let představuje historii diskurzu hodnou alespoň pojmenování a určitého přehledu. Pokládáme jej zároveň za podnět a výzvu pro autory, kteří by měli zájem pustit se do hlubší analýzy. Věríme, že i toto letmé shrnutí některých aspektů historie může mít pro čtenáře smysl v kontextu těch statí, které po něm v tomto čísle následují. Protože kritika vyprazdňování obsahu nabývá kulturní smysl, jestliže je namířena proti ztrátě védomí souvislostí jak s ohledem na hloubku porozumění, tak na kontinuitu historického vývoje. 